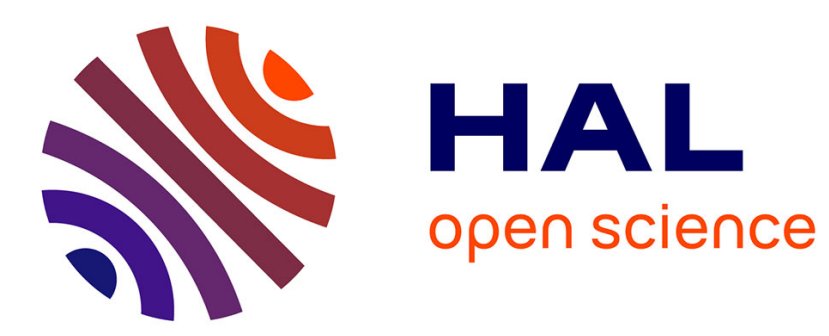

\title{
Plant pathology in the People's Republic of China: getting the job done
}

Cindy E. Morris, Philippe C. Nicot

\section{To cite this version:}

Cindy E. Morris, Philippe C. Nicot. Plant pathology in the People's Republic of China: getting the job done. Plant Disease, 1988, 72 (8), pp.648-660. 10.1094/PD-72-0648 . hal-02719774

\section{HAL Id: hal-02719774 \\ https://hal.inrae.fr/hal-02719774}

Submitted on 1 Jun 2020

HAL is a multi-disciplinary open access archive for the deposit and dissemination of scientific research documents, whether they are published or not. The documents may come from teaching and research institutions in France or abroad, or from public or private research centers.
L'archive ouverte pluridisciplinaire HAL, est destinée au dépôt et à la diffusion de documents scientifiques de niveau recherche, publiés ou non, émanant des établissements d'enseignement et de recherche français ou étrangers, des laboratoires publics ou privés. 
Cindy E. Morris and Philippe C. Nicot

Beijing Agricultural University, People's Republic of China

\section{Plant Pathology in the People's Republic of China Getting the Job Done}

In 1985 we began research in the Department of Plant Protection of Beijing Agricultural University (BAU) on vegetable diseases in multiplecropped production systems, sponsored by the Committee on Scholarly Communication with the People's Republic of China (CSCPRC) of the U.S. National Academy of Sciences. With the cooperation of our hosts, we have had the unique opportunity to extend our sojourn at BAU, and we have expanded our activities by organizing and lecturing in graduate-level plant pathology courses and directing the research of three master's degree candidates.

Here, we present our appraisal of the current status of plant pathology in China based on this experience and our visits to other agricultural research, teaching, and administrative institutions in Beijing and in Henan, Hubei, Guangdong, Sichuan, Shaanxi, Gansu, and Xinjiang provinces. (We use the official pinyin system of romanization for all names and words transcribed from the Chinese language.) For additional information we interviewed many faculty, staff, and students of BAU and other agricultural universities and surveyed the Chinese natural science literature published from 1985 to late 1987.

Our objective is to provide a comprehensive description of research and training in plant pathology as they are presently accomplished in China and of the associated administration, funding, and systems for publication. We have

- 1988 The American Phytopathological Society attempted to build on previous reports of plant pathology in China (3-5,7,9,12,15), and in so doing, we have stressed recent developments and what we foresee as future trends.

Western plant pathologists continue to be curious about disease control in China. Chinese plant pathologists are actively seeking contacts with Western counterparts, illustrated most recently by the scheduling of an International Plant Pathology Symposium in Beijing, 1-5 September 1988. We hope this report will be useful to both groups of plant pathologists by fostering an understanding of the background of students and scholars trained in China, the establishment of further collaborative projects, and an interest in the Chinese plant pathology literature.

\section{Historical Background}

In 1978, China initiated an effort to recast its science as part of the national policy for rapid modernization, and the subsequent changes over the past decade have been dramatic. However, testimonies of former eras of science policy are evident, particularly in plant pathology. To portray accurately the current status of plant pathology research and teaching in the People's Republic of China (PRC) we must first summarize briefly the history of China's science policy and organization.

From 1949 to 1966 , organization and administration of scientific institutions were influenced by the Soviet Union $(7,14)$. Universities became mainly centers of training, and separate research institutes were created (1). Russian replaced English as the main foreign language taught in universities. Lysenkoism temporarily predominated over Mendelian principles as the basis for teaching biology.

During the Cultural Revolution (1966-1976), research institutions were decentralized and the responsibility for their administration, funding, and scientific direction was placed at the local level. The practical knowledge held by the peasant and layperson and the expertise of the scientist had equal weight in the direction of these institutions. The first attempts were made to link scientific endeavors with production, and by 1967 almost all universities were closed or significantly reorganized and scientists were assigned to industrial or agricultural production units (2). The last 2 years of this period were particularly catastrophic for science (8).

After several years of effort to organize, the National Science Policy Conference convened in Beijing in March 1978 and laid the foundation for the First National Plan for Development of Science and Technology (1978-1985) (8). The plan was based on recognition of the necessary role of scientific research and training to achieve the goal of the "four modernizations." To ensure that science and technology serve economic construction, centralized control of scientific direction was reinstituted. Emphasis was placed on applied work, but basic science was not to be neglected. Universities became centers of research as well as training, and opportunities for research degrees at the master's and doctorate levels were created.

The Second National Plan for Development of Science and Technology began 


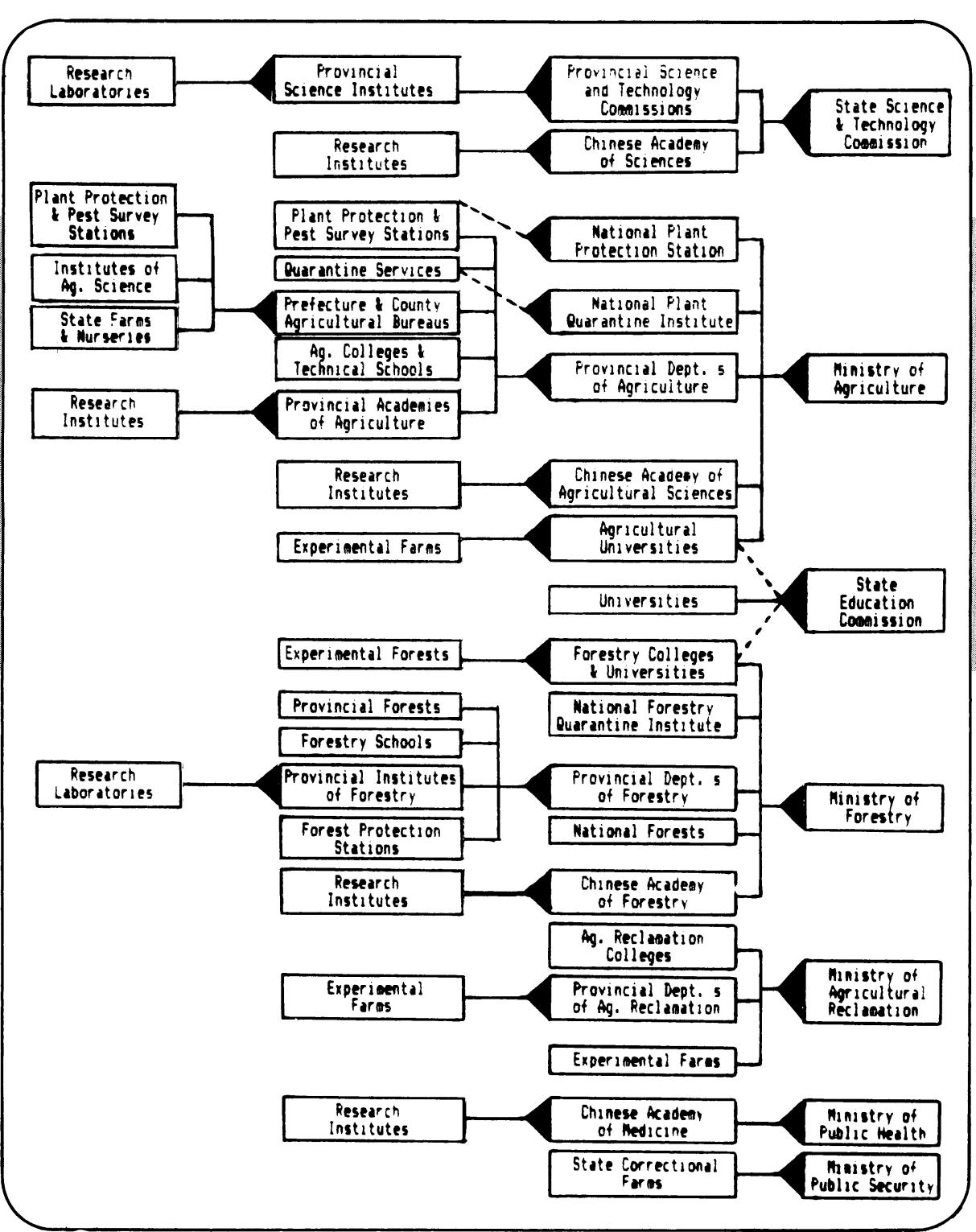

in 1985 and will be in effect until the end of this century (2). This plan is similar to the first but more closely links science and technology planning with economic development goals. According to this plan, a greater responsibility for leadership of scientific institutions is being given to scientific directorates than to Communist party cadres. More responsibility and opportunities for advancement are being given to junior scientists. This era has already seen establishment of a competitive grant system for research in the natural sciences and creation of opportunities for domestic training at the postdoctoral level. Both the first and the second plans have encouraged scientific exchanges with foreign scholars and establishment of collaborative research and training programs.

The first delegations of American agricultural scientists to visit the PRC were sent in the mid- to late 1970 s as obstacles to direct communication with Western scientists began to fade near the end of the Cultural Revolution. Plant pathologists were included in each of these delegations. They have provided detailed reports of the status of disease control practices and of research and teaching activities witnessed $(4,5,7,12)$. This was perhaps the beginning of efforts by Western plant pathologists to gain thorough understanding of what most of us know only vaguely as "the ancient tradition of disease control practices in China."

Since 1978, when the PRC officially normalized connunication between its scientists and their Western colleagues, numerous plant pathologists have come to China to lecture and discuss research interests. A few have come to conduct short-term research projects with their Chinese colleagues. These contacts have helped familiarize Western plant pathologists with the important plant
Fig. 1. Administrative relationships of institutions conducting research or teaching in plant pathology in China. Solid lines indicate flow of primary administration, funding, and directives. Broken lines indicate flow of additional directives.

diseases and methods used for their control in China and have also introduced the rationale used by Chinese plant pathologists to approach disease control problems and the impact of the social, political, and economic environment in which they work. But in the past decade, not only have new disease problems arisen in China, but dramatic changes in the political and economic climate have created opportunities for new directions of research in plant pathology.

\section{Organization, Administration of Research and Teaching}

The primary responsibility for research and teaching in plant pathology has been given to the universities, colleges, academies, state farms, and plant protection and quarantine stations that fall under the direction of the Ministry of Agriculture, Animal Husbandry and Fisheries, the Ministry of Forestry, and the State Science and Technology Commission. These include seven agricultural universities, three forestry universities, the Institute of Plant Protection of the Chinese Academy of Agricultural Sciences (CAAS), the Institute of Microbiology of the Chinese Academy of Sciences (CAS), the National Plant Quarantine Institute, the. National Forestry Quarantine Institute, and the National Plant Protection Station. Analogous institutions are administered at the provincial, municipal, prefectural, county, and city levels.

In addition, we have identified a variety of other institutions conducting research in plant pathology representing a total of seven ministries and state commissions (Fig. 1). These institutions 


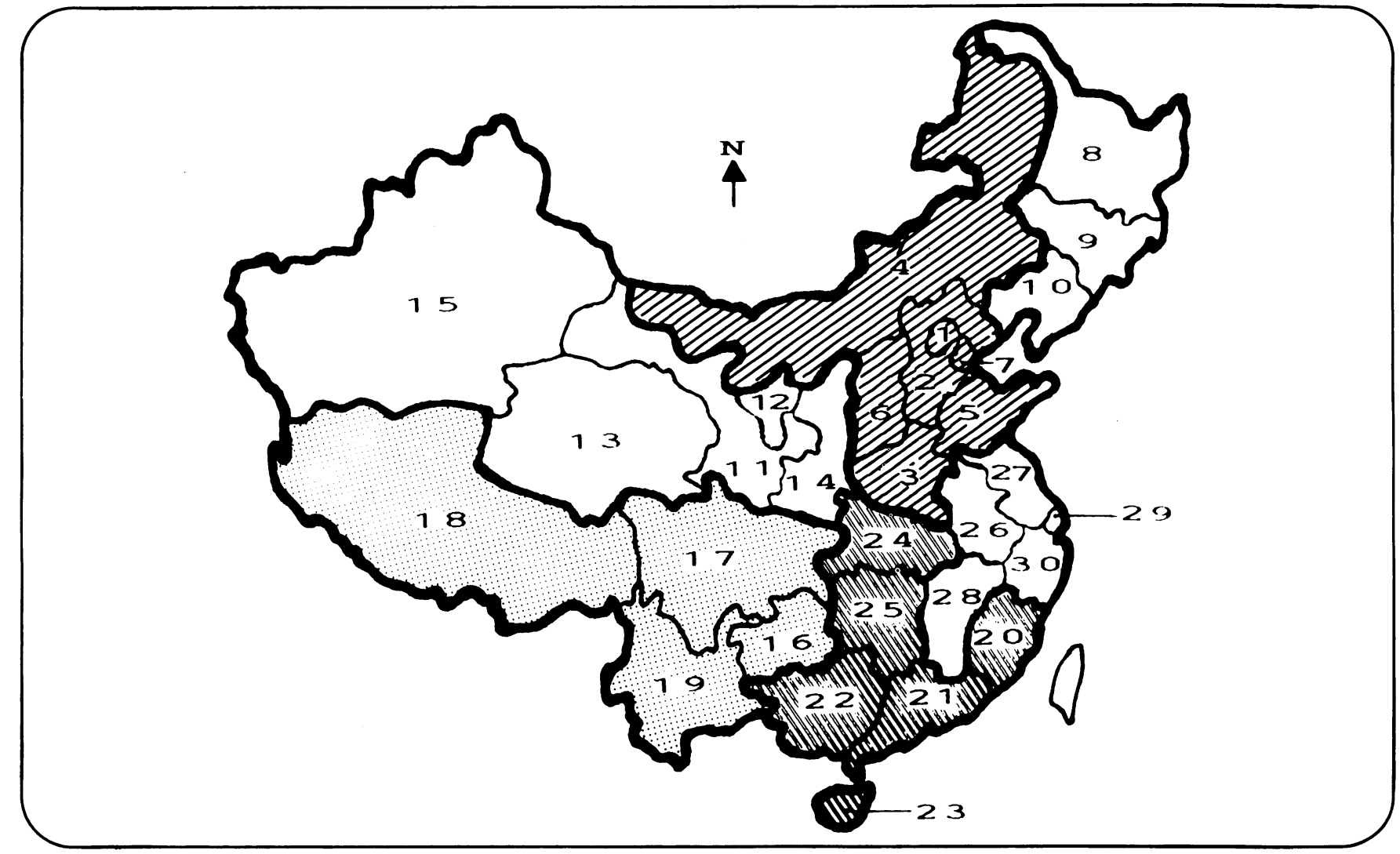

Fig. 2. The regional divisions of the Chinese Society for Plant Pathology. The number in each province, autonomous region, or municipality is explained in Table 1.

are as varied as the Production and Construction Corps of provincial departments of agricultural reclamation, the Institute for Medicinal Plant Development of the Chinese Academy of Medicine, and rehabilitation farms of state correctional institutions. (See references 1 and 2 for additional information on the national organization and administration of research institutions.)

\section{The Chinese Society for Plant Pathology}

To coordinate the activities and facilitate communication of plant pathologists nationwide, the Chinese Society for Plant Pathology (CSPP) was founded in Nanjing in 1929 (15). It suffered a brief eclipse during the Cultural Revolution when all scientific societies related to agricultural disciplines were disbanded and regrouped under the Association of Agriculture of the PRC (5). At present, CSPP has its headquarters at BAU and boasts nearly 2,800 members (including three international members) grouped in six regional divisions (Table 1, Fig. 2).

Membership. A complete directory of the membership is in preparation, but a partial list of members was published in early 1984. To establish this list, the administration of CSPP compiled information obtained from provincial societies of plant protection or directly from research units throughout China.
We estimate that this 1984 list represents over $70 \%$ of the current membership of CSPP, and that only minor changes may have occurred in the geographical and professional distribution of members.

The geographical location of CSPP members (Table 1) reflects the uneven distribution of plant pathology expertise in China. Over $55 \%$ of the members are concentrated in the nine coastal provinces and municipalities between Beijing and Guangzhou; Beijing and Guangdong Province alone have 17.3 and $14.4 \%$ of the members, respectively. More than $40 \%$ of CSPP members work in research institutions, whereas only $25 \%$ work in universities or colleges and nearly $25 \%$ hold extension or administrative positions for the central or local governments (Table 1). It is worth noting that about $40 \%$ of the members work at the grassroots level in prefectural, county, or city research or administrative institutions or in agricultural schools. The single agroindustrial representative in CSPP is from a Shanghai pesticide factory.

To be eligible for membership in CSPP, one must have worked in a field related to plant pathology for 2 years after obtaining a bachelor of science degree. Hence, graduate students are generally not members. Young graduates from master's or doctorate programs often join after they leave the university and are assigned to a work unit. Plant pathologists usually become members of the national organization as a consequence of joining the plant protection society of their province or the CSPP division of their region. Membership fees are currently not collected from Chinese members of CSPP, but there is a yearly membership fee for the regional divisions.

Administration. The CSPP is adminstered by a council of 39 members, 21 from the Beijing area and 18 elected by the six regional divisions. The council in turn elects its officers. With few exceptions, these officers are senior members of CSPP who have vast experience in research and administration and who have been active in the field of plant pathology since the 1930s. The names of the officers of the current council of CSPP, which will remain in office until the next national meeting, can be found in Acta Phytopathologica Sinica (15[4]:223, 1985). In organizing the activities of CSPP, the council is assisted by 10 standing committees. These are (see Acta Phytopathologica Sinica 16[1]:56 and 62, 1986): Meetings and General Organization Committee (Han Jin-sheng, BAU, chairman), Domestic Academic Exchange Committee (Chen Yan-xi, BAU, chairman), International Affairs Committee (Shen Jingpu, Foreign Affairs Office, CAS, chairman), Extension Committee (Li Ming-yuan, Beijing Academy of Agriculture, Institute of Plant Protection, chairman), Editing and Publication Committee (Han Jin-sheng, BAU, chairman), Plant Disease Epidemic 


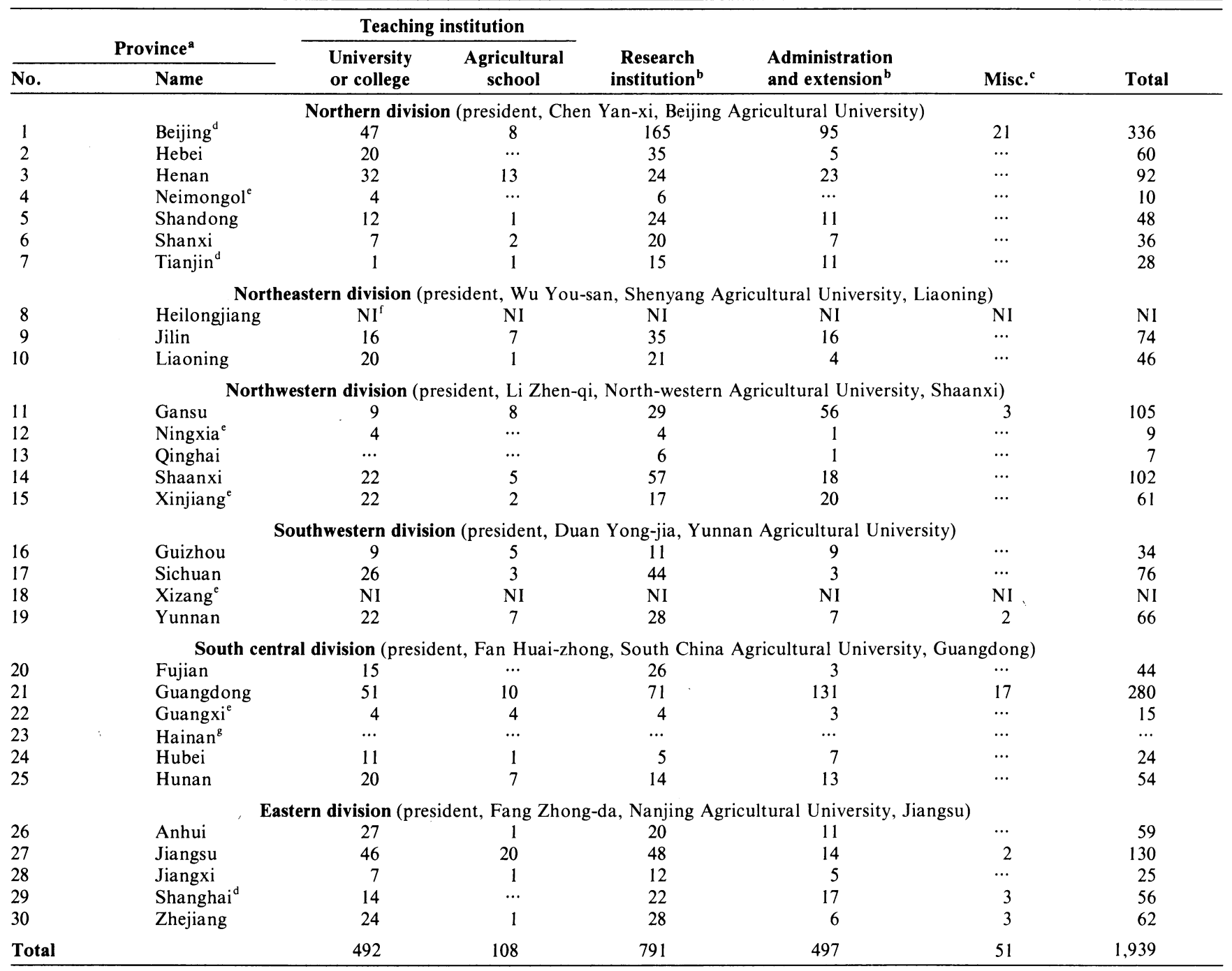

${ }^{\mathrm{a}}$ See Figure 2 for corresponding numbers.

${ }^{b}$ Supported at national, provincial, prefectural, country, or city level.

${ }^{\mathrm{C}}$ State farms, communes, and one pesticide factory.

${ }^{\mathrm{d}}$ Municipality (same administrative status as province).

${ }^{\mathrm{e}}$ Autonomous region (same administrative status as province).

${ }^{\mathrm{f}} \mathrm{NI}=$ no information available.

${ }^{\mathrm{g}}$ Information included with that for Guangdong (Hainan Island became a separate province in 1988).

Forecast Committee (11 members, Zeng Shi-mai, BAU, chairman), Plant Breeding for Disease Resistance Committee (19 members, Chen Shan-ming, Institute of Plant Protection, CAAS, chairman), Bio-control and Soilborne Diseases Committee (15 members, Chen Yan-xi, BAU, chairman), Development and Application of Disease Control Technology Committee (13 members, Liu Song-lin, National Plant Protection Station, chairman), and (created in 1987) Biology of Plant Pathogens Committee (Fang Zhong-da, Nanjing Agricultural University, chairman).

Domestic activities. The most conspicuous activities of CSPP are the publication of the journal Acta Phytopathologica Sinica and the organization of the national meetings every 4 years. The last national meeting was held in
Beijing in October 1985. It was the second one held since the Cultural Revolution (the first was in 1982) and was attended by more than 400 members from all over China. The 5-day meeting included general sessions, a day of presentations in small interest groups, and a poster session. The topics for the talks were selected by the CSPP council, and all speakers were invited. Most speakers in the general sessions were senior members of CSPP and often officers of the society. Poster presentations were not solicited, and a wide variety of information was presented among the nearly 50 posters. Over 600 abstracts were contributed, and a compilation of these was published and distributed to the participants of the meeting.

For practical reasons, the last national meetings have been held in Beijing and, presumably, so will future ones. In addition to coordinating professional activities, the Meetings and General Organization Committee has the difficult task of locating and supervising premises that can provide a large meeting room as well as housing and dining halls for 400-500 participants. There is no registration fee to attend the meeting. The work units of the participants pay for housing and food, and the budget of CSPP absorbs all costs related to renting the premises as well as the round-trip transportation expenses of each participant. One person of the Meetings and General Organization Committee has the formidable task of booking and purchasing the return tickets at the Beijing railway station and airport for all out-of-town participants.

Other activities of CSPP include the 
identification of important research topics and promotion of academic exchanges. During 1982-1983, research groups were organized nationwide to study rice diseases and pests and integrated pest control. The publication of the reports and dissemination of information was also ensured by CSPP. In late 1983, a small-scale national workshop on fruit tree disease research was organized in Kunming, Yunnan Province, and plans were drawn to coordinate a national investigation on soilborne diseases of field crops and to hold a meeting in 1984 for the presentation of research results. Some activities of CSPP are done in cooperation with or at the request of local plant pathology societies. In 1983, the Beijing Society for Plant Pathology invited officers of CSPP to give reports on various topics and advice on crop production and also to assist in the publication of booklets and slides on vegetable diseases.

International activities. In the last few years, an increasing number of CSPP members have attended national plant pathology meetings outside China. The CSPP has officially participated in the International Society of Plant Pathology since its Fourth International Congress in 1983, and as many as 50 CSPP members are expected to attend the Fifth International Congress in August 1988 in Kyoto. The CSPP will organize its First International Plant Pathology Symposium to be held in Beijing 1-5 September 1988 and hopes for a wide international participation. The symposium will be supported by funds from the Chinese Association for Science and Technology (CAST) and the Ministry of Agriculture. (See reference 1 for a description of CAST.) In 1987, a workshop on disease management and resistance breeding was held in Beijing and jointly sponsored by CSPP, the Plant Protection Division of the Food and Agriculture Organization of the United Nations, and the Chinese Ministry of Agriculture.

Budget. The largest part of the income of CSPP consists of subsidies from CAST amounting to 30,000-40,000 yuan (Y) yearly (Y1.00 = U.S.\$0.27). Annual revenue from the sale of Acta Phytopathologica Sinica is estimated to be nearly Y 19,000. Publication costs are one of the major yearly expenses, estimated at about Y44,000, leaving only about Y 10,000 for the other regular activities of the society. Additional funds are presumably obtained from the state to finance occasional activities such as the national meetings. The contrast between the paucity of funds and the profusion of achievements of CSPP bears witness to the devotion and resourcefulness of its officers and members. In the future, budgetary problems might be lightened by such income-generating activities as publication of books and teaching materials and sale of CSPP memorabilia.
The six regional divisions of CSPP were created in 1985, and each derives one-third of its revenue from the national society. The major part of their income is provided by local governments and a small fraction is from the annual membership fees. Regional divisions hold separate annual meetings focused on local problems.

The Chinese Plant Protection Society was created in 1963 to foster academic exchanges in the fields of entomology and pesticide application as well as plant pathology. The structure of the Plant Protection Society (PPS) parallels that of CSPP, and the types of activities of the two societies are similar. Many members of CSPP also join PPS. However, PPS has a strong emphasis on applied research and pest control, as reflected by the contents of the journals it publishes, Acta Phytophylacica Sinica and Plant Protection. Delegates of PPS attended the conferences of the International Congress of Plant Protection in 1979, 1983, and 1987. The Plant Pathology Society was incorporated into the Plant Protection Society in 1963 but reappeared as a separate society at the end of the Cultural Revolution. The complementarity of their activities may explain the survival and parallel growth of these two societies without too much competition.

\section{Research Activities}

In China, plant pathology research is conducted at 1) the research and teaching institutes at the national, provincial, and local levels and 2) the various plant and forest protection and pest survey stations, state farms, forests, and nurseries. Research by the latter organizations is designed for direct application, and little of it is published broadly. This research is focused on quality testing of nursery stock and seeds, variety improvement through breeding and selection, and evaluation of disease control measures. Much of the research in the former institutions is destined for publication and eventual application through cooperation with the latter groups. The summary of research activities presented here is based on our knowledge of researchers associated with the former organizations, as they are the majority of active plant pathologists in China.

In research and teaching institutions, staff are members of research groups with a particular focus. Within the division of plant pathology in universities or in plant protection institutes, faculty and graduate students may be members of, for example, a mycology and fungal disease research group, a disease physiology research group, or an epidemiology research group. Research groups consist of several to a dozen faculty members and up to about 20 graduate students. Although research projects are usually assigned to graduate students, faculty members choose their own research topics within the scope of their group.

\section{Present Research Topics}

To determine the range and balance of recent research topics in plant pathology, we categorized, according to pathogen, host, and field of study, the 174 research articles and notes published in Acta Phytopathologica Sinica and Acta Phytophylacica Sinica from 1985 to late 1987. To this list were added plant pathology-related articles published in all other accessible Chinese natural science journals in 1987 and also information collected at the national CSPP meeting in 1985 and during visits to research institutes. From this compilation it is clear that studies of pathogens of wheat (viz., Puccinia striiformis, Erysiphe graminis f. sp. tritici, and wheat yellow dwarf virus) and of rice (viz., Xanthomonas campestris pv. oryzae and Pyricularia oryzae) have dominated over the past decade $(5,9)$. These and other diseases have been reported in the lists of important diseases in China published during the past decade $(3-5,9,12)$. Rather than reiterate these extensive lists, we have summarized the topics of study to illustrate the recent trends in plant pathology research in China.

Hosts (listed in order of decreasing research importance). Grains. Pathogens of quarantine concern, such as Erwinia stewartii, have become important objects of research. Recent attempts have been made to promote sweet corn, and certain foreign seed companies have established offices in China. Both have caused increased seed corn importation and the threat of introduction of this pathogen.

Vegetables. Diseases of the most popular vegetables-Chinese cabbage, cucumber, and tomato-have been studied intensively since the 1950 s. These include Erwinia carotovora pv. carotovora and turnip mosaic virus of Chinese cabbage, Peronospora parasitica of cucumber, and tobacco mosaic virus (TMV) and cucumber mosaic virus (CMV) of tomato. Since the early 1980s, farmers have been permitted to sell surplus vegetables on the free market. As a result, consumers have begun demanding higher quality vegetables, and interest in diseases of a wider variety of vegetables has increased. To meet the growing demand, production methods have intensified, with marked consequences on vegetable diseases. Williams (12) noted that in 1979 , plastic shelters were used for early-season vegetable production to avoid diseases such as late blight of tomato. But in the Beijing area, for example, an estimated $43 \%$ of the current vegetable production area is now cropped under plastic throughout the year and late blight of tomato has become a serious problem. These shelters 
(Fig. 3) have now become sources of inoculum for many vegetable diseases.

Fruits. The bulk of recent work has been on detecting and controlling pathogens of the melon (Cucumis melo) cultivar Hami (viz., CMV, squash mosaic virus, watermelon mosaic virus, Hami necrosis virus, and Phytophthora melonis). Although $\mathrm{Hami}$ melon is produced almost exclusively in Xinjiang Province, improved transportation has made it readily available and popular in the eastern provinces. Studies on apple bark rot (Valsa mali) and some apple viruses are also dominant among work on fruit diseases.

Fiber crops. Research on cotton diseases, primarily Fusarium and Verticillium wilts, has been important over the past decade. Interest in these diseases is increasing in parallel with efforts to improve the fiber quality of Chinese cotton for export. Other fiber crop pathogens being studied are Pseudomonas solanacearum of mulberry (the food source for silkworms) and rootknot nematodes of kenaf (Hibiscus cannabinus).

Cash crops. These are produced in large part on Hainan Island, formerly part of Guangdong Province but recently designated as a special economic zone and a separate province. These changes will eventually improve the financial situation for research on the island. The currently studied diseases of vanilla (Sclerotinia and Fusarium root rots), of cocoa (black pod disease caused by Phytophthora palmivora), and of black pepper (stem rot caused by P. palmivora) may receive even more attention. Since 1979 the South China Academy of Tropical Crops on Hainan Island has strived to establish rubber groves from single clones generated through tissue culture for large-scale rubber production north of the 15th parallel. Studies of leaf blight (Periconia hevea) and powdery mildew (Oidium heveae) may become more important as rubber production intensifies on the island.

Pathogens of tobacco (TMV, CMV, and Phytophthora parasitica var. nicotianae) are also under study. Generous research support from the tobacco industry, establishment of a Tobacco Institute of the Chinese Academy of Agricultural Sciences, and lack of a widespread antismoking campaign suggest that tobacco research will increase.

Ornamentals and forest trees. Studies on the ecology, biology, and control of pathogens of timber and spice crops, of forest trees and ornamentals, and of the multipurpose bamboo are being conducted. Examples include studies of the life cycle of the spruce rust (Chrysomyxa gilianenses) indigenous to Qinghai Province; the life cycle and control of leaf rust (Melampsora pruinosa) of mature and nursery seedling poplar; control of anthracnose of Chinese anise tree (Illicium chinensis) seedlings; and the biology and taxonomy of the pathogens causing witches'-broom of bamboo. Most of this research has been published in special forestry-related journals such as Forest Pest and Disease. Efforts to reforest the northern "Green Belt," to forest some of the northwestern desert areas (Fig. 4), and to beautify cities have contributed to the interest in these plants.

Medicinal plants. Traditional Chinese medicine is widely practiced, and medicinal plants are profitable crops that are carefully cultivated. Numerous institutes are responsible for studies of diseases of medicinal plants, including the CAAS Special Wild Economic Animal and Plant Research Institute and the Institute of Medicinal Plant Development of the Chinese Academy of Medicine. The latter institute maintains a staff of about five plant pathologists. Crops and their pathogens under study include Cylindrocarpon sp., Alternaria panax, and Fusarium spp. of ginseng; Erwinia carotovora pv. carotovora and Septoria lysimachiae of Lysimachia foenum-graecum (used in birth control and as an insect repellent); Pyricularia sp. of Amomum villosum (for cold medication); and Meloidogyne hapla of Vinca minor (source of the alkaloid resperine used to treat hypertension). Chinese scientists are actively working to determine the mechanisms by which certain traditional treatments are effective. This may lead to increased popularity of these treatments and further interest in the diseases of medicinal plants.

Oil crops. Pathogens being studied are Puccinia arachidis and peanut mild mottle virus, Puccinia carthami of safflower, and Sclerotinia sclerotiorum and unidentified viruses of rape.

Fields of study. In their 1977 report, Kelman and Cook (5) noted that little work was being done in China on disease physiology; the biochemistry of disease resistance; multiplication, structure, or molecular biology of viruses; or the ecology of soilborne pathogens. Most work at that time had direct application to control, and little emphasis was placed on studies of basic biology. Our survey of the recent plant pathology literature illustrates that opportunities and resources for studies of basic biology have arisen in the past decade. The fields of study represented in the 174 articles surveyed (followed by the percentage of the total number of articles in parentheses) include etiology $(20 \%)$, qualitative epidemiology (15\%), methods of disease control (13\%), screening for and inheritance of disease resistance (13\%), pathogen biology (12\%), quantitative epidemiology ( $8 \%$ ), development of new races and strains of pathogens $(8 \%)$, methods of detecting pathogens $(6 \%)$, and physiology of disease (5\%).
Chinese plant pathologists are actively diagnosing newly recognized diseases, about one-half of which are caused by viruses and about one-third by fungi. This balance may not represent the relative importance of these pathogens in the field, however (4). In the area of qualitative epidemiology, studies of insect transmission of viruses of wheat and soybean and of the citrus yellow shoot pathogen predominate. Next in level of frequency are studies to determine disease cycles and sources of inoculum.

Among studies of disease control, those involving application of synthetic chemicals predominate, reflecting very active research in pesticide synthesis. However, studies involving biological control or natural plant or microbial products are numerous. This is in contrast to previous remarks of little application in China of biological control for managing plant diseases $(3,12)$. Researchers at the CAS Institute of Microbiology are studying use of a satellite of CMV for control of this virus on tomato and chili pepper. Use of bacteriocins to control Xanthomonas campestris pv. oryzicola and Pseudomonas solanacearum is being studied at Fujian Agricultural College and Nanjing Agricultural University, respectively. Researchers at BAU and the CAS Institute of Microbiology are attempting to develop an effective bacteriocin for biotype III of Agrobacterium tumefaciens.

Studies of plant growth-promoting soil microbes have recently resulted in widely marketed biocontrol products. The Department of Plant Protection of Zhejiang Agricultural University produces a preparation of Trichoderma harzianum for controlling a disease of jasmine caused by Rhizoctonia solani. The BioControl Research Group at BAU produces a "plant yield-increasing" bacterial seed dressing that is currently used on about 70,000 ha of rape in Hunan, Sichuan, and Anhui provinces.

Many plant extracts are being tested for their biocidal activity or ability to induce host resistance. Among the most successful is compound NS-83, an extract from rape oil developed by the Plant Virology Research Group at BAU that is effective in controlling numerous viruses if applied before infection. At South China Agricultural University, the Toxicology Division of the Department of Plant Protection maintains an extensive garden of plants with medicinal, insecticidal, and fungicidal properties. Extracts from Lycoris radiata, high in alkaloids, have been found to inhibit Phytophthora infestans and Pyricularia oryzae.

Particularly novel among the current studies is the application of an industrially produced surfactant for control of foliar and storage diseases. The surfactant, 
referred to as a "monomolecular filmforming substance," is composed primarily of unsaturated $\mathrm{C}_{10}$ fatty acids. It is sprayed directly on foliage with a conventional pesticide sprayer or can be applied as a fruit dip. Biweekly applications by researchers at BAU for control of apple scab resulted in an incidence of diseased fruits of $9 \%$ compared with $6 \%$ for Bordeaux-treated trees and $72 \%$ for untreated trees. The surfactant can also be used to protect plants from drought stress by reducing transpiration.

Research on pathogen biology includes studies of resistance of Ustilago maydis and Penicillium digitatum to fungicides; heterokaryosis in Rhizoctonia solani, Botrytis squamosa, and Fusarium spp.; and hyperparasitism of larch rust (Triphragmiopsis laricinum) by Darluca filum and of Meloidogyne incognita by Verticillium insectorum.

Models of disease progress and prediction of epidemics of stripe rust of wheat (Puccinia striiformis) continue to predominate quantitative epidemiologic studies. Attempts are also being made to quantify disease incidence and yield loss caused by asparagus lettuce mosaic virus, Agrobacterium tumefaciens on grape, and Venturia inaequalis. Applications of

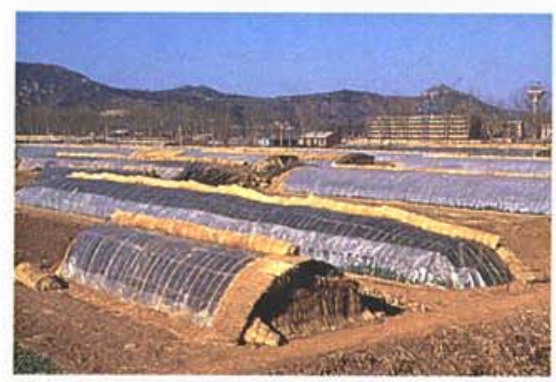

Fig. 3. Plastic shelters to extend the growing season for vegetables in northern China are used so intensively that they have become sources of disease inoculum. Loss of agricultural lands to urban expansion increases the need for such intensive crop production.

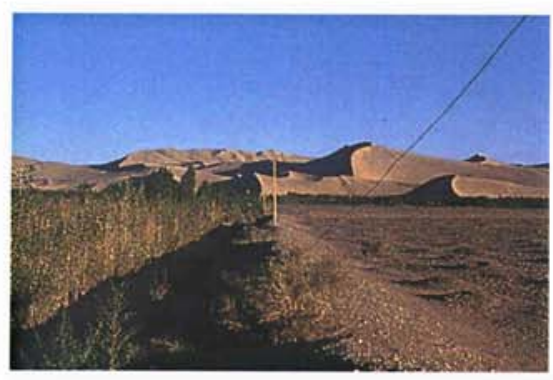

Fig. 4. This agricultural field in Gansu Province is one of many being reclaimed from China's northwestern deserts. Poplars are frequently used in desert reclamation and may suffer from multiple diseases in this stressful environment. "fuzzy pattern recognition" techniques for quantitative epidemiology are being introduced.

New methods for rapidly detecting or identifying pathogens are primarily serological for viruses. However, the National Plant Quarantine Institute has developed a method whereby the identity of presumptive Erwinia stewartii isolates is verified within 12 hours after isolation by screening against eight bacteriophages. Studies of disease physiology include the basis of resistance of wheat to Erysiphe graminis f. sp. tritici and Puccinia spp. and of tomato to TMV. Physiological effects of environmental pollutants, e.g. fluoride damage to mulberry, are also under investigation.

Molecular biology studies of plant pathogens have also begun. A cooperative project in molecular virology is commencing between the Plant Virology Research Group at BAU and the Biology Department at Beijing University (Fig. 5). Researchers at Nanjing Agricultural University have recently reported employing transposon Tn5-induced mutagenesis to study the genetic regulation of bacteriocin production by Erwinia chrysanthemi. More opportunities for studies of molecular biology in China should arise as the financial situation for research improves and the number of pathologists with advanced training increases.

\section{Factors Influencing Selection of Research Topics}

In selecting research topics, Chinese plant pathologists are influenced by the same basic factors influencing their Western counterparts, viz., availability of funds, access to resources, importance of certain crops and their diseases, their own interest and expertise, and the leadership of their research unit. Here, we present our impression of what has contributed to the importance of each of these factors.

Research funds. National funds for plant pathology research are administered by the Ministry of Agriculture. These

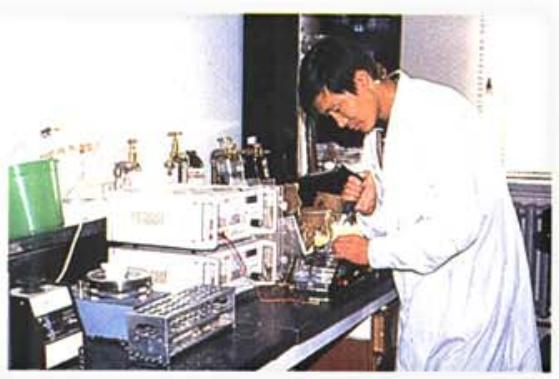

Fig. 5. This Ph.D. candidate from Beijing Agricultural University's Plant Virology Laboratory (shown in a laboratory of Beijing University's Biology Department) is working on isolating and cloning the coat protein genes of carnation mottle virus. funds are part of the total budget for plant protection and are divided among research and extension activities for control of weeds, rats, and insects as well as pathogens. During the last Five-Year Plan for economic development (1980-1985), Ministry of Agriculture grants for a single project in plant pathology amounted to Y20,000-30,000 per year. Grants to workers in research institutes have generally been more abundant and generous than those to university staff, reflecting the old attitude about the role of the universities. Ministry grants have often been insufficient for purchasing all the necessary equipment and hiring technical help. Hence, researchers have sought additional funds from provincial and city governments, from university administration, and from industry.

The close link of plant pathology research with industry is conspicuous. Many of the marketable products from the research described above are being produced and sold, either in direct cooperation with a manufacturing unit independent of the research group or by the research group itself. Chemicals for disease control are synthesized and marketed by various research units, including the CAAS Institute of Plant Protection. Production of microbial agents or their by-products has also become big business. The Bio-Control Research Group of BAU operates a factory, on university grounds, to produce annually about $1,000 \mathrm{t}$ of its "plant yield-increasing" bacterial agent. Part of the income from the factory is used to fund the group's research, and part of the government funds for this research are used to support the manager and 30 technicians operating the factory.

Before the $1980 \mathrm{~s}$, the nationally administered research funds for agriculture were distributed on a noncompetitive basis. Consequently, many research efforts were duplicated. But in the surge toward modernization in the 1980 s, the research community expanded rapidly and greatly taxed the Ministry of Agriculture's budget. In 1986, the National Natural Science Foundation (NNSF) - with a budget of several hundred million yuan (1) - began to include applications from researchers outside of the CAS for consideration in the awarding of competitive grants. In early 1987, the Ministry of Agriculture announced that funding priority would be given to applied studies and that workers in basic areas could turn to the NNSF. We recall the intense efforts of research groups at the time of this proclamation to rethink the direction of their projects and establish at least one project with direct short-term application. Hence, there are now plans for commercial and recreational ice production catalyzed by ice-nucleation-active bacteria and large-scale production and marketing of 
agrocin 84 and NS-83, among others.

With more emphasis on applied work, a natural source of funds is industry. Hence, the link of university research with industry interests is becoming closer. Other sources of funds for plant pathology are the ministries listed in Figure 1 or ministries involved in storage or transportation of food. Because of their proximity to the seat of the ministries, researchers in Beijing have a distinct advantage over those in the rest of the nation for access to a diversity of funding sources.

Level of expertise. The Chinese scientific community can be divided into three groups corresponding to opportunities for advanced training, i.e., those who received their education: 1) before the early $1950 \mathrm{~s}, 2$ ) between the early 1950s and about 1980 , and 3) after 1980 . The training of researchers in the second group, in particular, who are currently in their late 30 s to early $50 \mathrm{~s}$, suffered from the adoption of Lysenkoism, the disruption of the universities during the Cultural Revolution, and the lack of advanced training. Researchers in this age group are making a remarkable effort toward self-improvement through continued training, but some plant pathologists have confidence only to perform routine tasks or be involved in etiologic studies.

Importance of crops and disease problems. In China, sociological and production factors have markedly influenced which crops and diseases are important at any given time. These factors have been in large part a consequence of the prevailing agricultural policy. Before the 1950 s, China's agricultural production was characterized by regional specialization and interregional trade. The tea and medicinal herbs produced in Yunnan Province, the timber in Hunan, the sugarcane in Fujian, and the cotton in Hebei, for example, were traded for wheat and rice produced in other regions (6). During the Great Leap Forward (1958-1960), the policy of local self-sufficiency in grain production was introduced. Rice and wheat production were attempted in many unsuitable regions, and some of the habitats for traditional crops were destroyed. Regions that had been the main grain producers prior to 1958 attempted to produce the timber, sugarcane, and cotton for which they had previously traded. After 1979, China began to readjust slowly to the old pattern of regional specialization. Although there has been no attempt to examine the actual impact of these policy changes on the prevailing disease problems, it is likely that such dramtic shifts in the agroecosystems contributed to some disease problems. Nevertheless, the significance of grain production in the national agricultural policy was accompanied by a strong focus on diseases of grains.

In the mid-1980s, the people's communes gradually disbanded and the "household contract responsibilty system" for crop production was introduced (14). Some former communes have maintained, to varying degrees, collective efforts for disease and pest control. But in many villages, individual households have assumed responsibility for protecting the crops on their landholdings. In addition to a scarcity of effective pesticides, there is also a paucity of educational resources, as each household seeks access to manuals, booklets, and plant protection station staff. A second consequence of the disbanding of the communes is a loss of some expertise in traditional production methods. Heads of households who were in their formative years during the era of the communes may have no experience in the decision making involved in application of traditional disease control methods. The small landholdings also make it difficult for the farmers to practice the complex rotational sequences observed formerly (7). New disease problems may be emerging as a consequence.

Along with the contract responsibility system came a loosening of control on employment in industry. The percentage of the rural labor force employed part- or full-time in local small industries increases yearly. Consequently, sufficient labor is not available for such laborintensive control practices as roguing. Collection and application of manure or other organic fertilizers is another laborintensive process that has declined. This could be due in part to an increase in production and distribution of chemical fertilizers, which may have caused some farmers to neglect traditional organic fertilization. Although no direct relationship to use of chemical fertilizers has been demonstrated, farmers have noticed that the incidence of soilborne diseases, particularly of vegetables, is on the rise (Fig. 6).

Diminishing labor resources is also prompting farmers to use mechanization

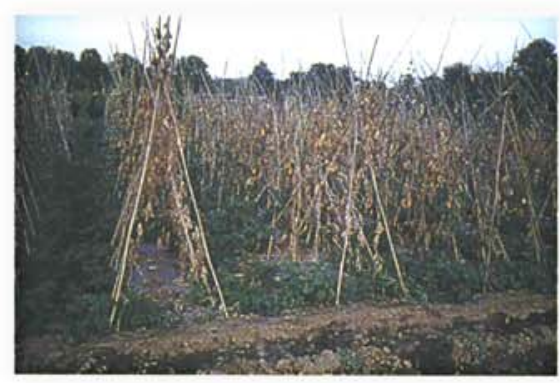

Fig. 6. Many soilborne diseases that were formerly of little consequence in China are becoming increasingly important. Nearly all of the cucumber plants in this field, photographed in summer 1986, were destroyed by Fusarium oxysporum before the fruit could be harvested. as much as possible (Fig. 7) and, in so doing, to neglect field sanitation. We have observed cabbage debris being plowed into fields with a tractor after harvest, which contrasts sharply with previously reported (12) care given to sanitation. Because of the desire to use tractors for tilling, neighboring farmers may plant large contiguous fields to a single crop, thus reducing the amount of multiple cropping practiced.

Resources. Field plots. Disbanding of the people's communes has made it difficult to conduct field experiments at units with no associated or convenient experimental farms. BAU is one such example. During the era of the communes, sufficient land and labor were available from the neighboring commune, and at least one production brigade was responsible for experimental studies. They readily cooperated with researchers in doing field experiments (9). But at present, in villages that have not continued some collective farming, individual households each maintain only about $0.2-0.5$ ha, and there has been a drastic loss in farmer cooperation. Researchers might rent land from farmers and pay for labor at a cost of up to $\mathrm{Y} 4,500 /$ ha per season. An alternative to renting land is to establish a collaborative project with county-level plant protection stations. These stations generally have established trusting relationships with local farmers and can facilitate cooperation. Many agricultural colleges, universities, and research institutes have convenient access to experimental farms (Fig. 8) ranging in size from about 50 to 1,000 ha, depending on proximity to urban centers. Use of the land may be free or cost about $\mathrm{Y} 1,500 /$ ha.
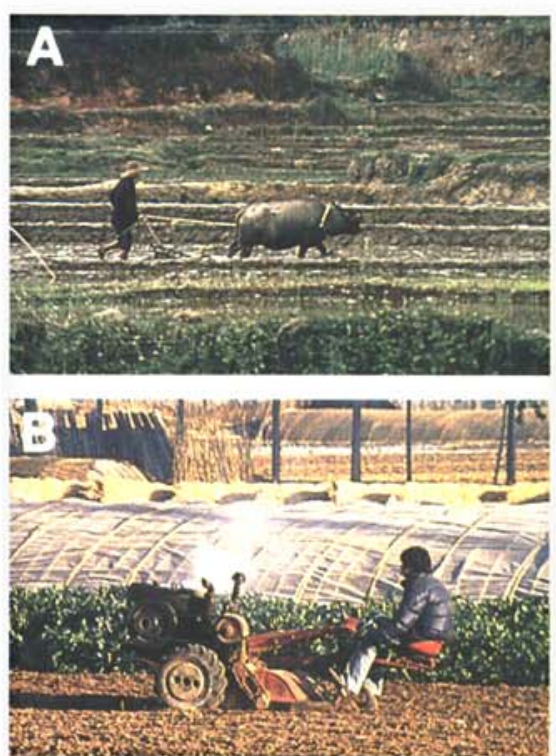

Fig. 7. (A) Although horse- and ox-drawn plows are still widely used by Chinese farmers, (B) the use of tractors is on the rise and is affecting cropping patterns. 
Electricity and water. Until generation of electricity and purification and storage of water can meet demands, China will continue to ration these resources. Water pressure may be cut completely at night, individual research groups must pay for all electricity and water consumed, and financial penalties are issued for overuse. Especially heavy consumers of electricity (e.g., laboratories operating greenhouses, growth chambers, centrifuges, etc.) may have their electricity cut for several consecutive days as a penalty. Operation of large growth chambers is particularly problematic. The $10-\mathrm{kw}$ motor and lights of a $4.5-\mathrm{m}^{3}$ growth chamber may consume up to Y 60 of electricity daily (1 kwh costs Y0.25). Special storage containers must be constructed to permit recirculation of water used to cool the chambers.

Technical help. In general, two types of employees are available for technical help. Some research groups include tenured workers who have received in- house training but who have little additional background in science. There is also a large body of temporary workers, often children of nearby fa:mers, who are hired to help during a busy harvest season or to wash dishes. Although the agricultural schools offering 2-year degrees should be a source of skilled technical help, very little help is available. Very few undergraduate students work in laboratories during the summer recess and even fewer during the school year. In the universities, "young teachers," recently graduated from a bachelor's or master's degree program, may be part of a research group. But much of their time is taken by advising and teaching undergraduates. Skilled technical help is in great shortage. Those laboratories in need of much technical help must invest a lot of time in training. Laboratories in urban centers must also contend with a high turnover rate, as permissible salaries for technical workers are less than one-third of what could be earned in a hotel or restaurant.

Equipment. Currently, the equipment necessary for everything from simple light microscopy to generation and application of monoclonal antibodies and cDNA probes is available for purchase by Chinese researchers either through domestic sources or by importation. The limiting factor is money, and for Chinese researchers this limitation is often compounded by a lack of cooperation among research groups to purchase equipment collectively or to share. Most research institutes, universities, and colleges have established a so-called central research laboratory, a building housing gas chromatographs, scanning spectrophotometers, light microscopes, an electron microscope, centrifuges, etc. This equipment has often been purchased with World Bank or national foreign aid program monies. Such equipment is maintained and operated by specially trained staff members, and researchers pay for unit

Table 2. Chinese scientific journals that publish research articles related to plant pathology

\begin{tabular}{lll}
\hline & \multicolumn{2}{c}{ In English" } \\
\cline { 2 - 3 } Journal title & TC AB TF & Contents related to plant pathology \\
\hline
\end{tabular}

\begin{tabular}{|c|c|c|c|c|}
\hline \multicolumn{5}{|c|}{ Journals published by national science or agriculture academies or national scientific societies } \\
\hline Acta Agronomica Sinica & + & + & - & Sources of disease resistance \\
\hline Acta Mycologia Sinica & + & + & + & $\mathrm{V}$; fungal taxonomy, storage, and propagation; fungal toxins \\
\hline Acta Phytopathologica Sinica & + & + & - & See text \\
\hline Acta Phytophylacica Sinica & + & + & - & See text \\
\hline Agro-Environmental Protection & + & - & - & Pollution damage to plants; pesticide safety and residuals \\
\hline China Fruits & + & - & - & Disease epidemiology and control \\
\hline Chinese Journal of Biological Control & + & + & - & $\begin{array}{l}\text { Ti plasmid types and agrocin } 84 \text { effectiveness; control of CMV } \\
\text { with satellite RNA; antimyocin } 120 \text { effectiveness }\end{array}$ \\
\hline Chinese Vegetables & + & - & - & Disease epidemiology and control \\
\hline Crop Genetic Resources & + & - & - & Sources of disease resistance \\
\hline Edible Fungi of China & + & - & - & Survey of diseases \\
\hline Forest Pest and Disease & + & - & - & $\begin{array}{l}\text { Ecology, biology, and control of pathogens of timber, spice, } \\
\text { ornamental, and forest trees }\end{array}$ \\
\hline Rural Eco-Environment & + & - & - & Pesticide safety and residuals \\
\hline Scientia Agriculturae Sinica & + & + & - & $\begin{array}{l}\mathrm{V} ; \text { host and parasite genetics and variability; mechanisms } \\
\text { of resistance }\end{array}$ \\
\hline Scientia Silvae Sinica & + & + & - & $\begin{array}{l}\text { Physiology of resistance of olive and Camellia spp. to Colletotrichum } \\
\text { spp.; etiology of witches'-broom of Pterocarya stenoptera }\end{array}$ \\
\hline Scientia Sinica (Series B) ${ }^{c}$ & + & + & + & $\begin{array}{l}\text { RNA molecule types of burdock stunt viroid; cytokinin effect } \\
\text { on tomato resistance to TMV }\end{array}$ \\
\hline
\end{tabular}

Acta Agriculturae Boreali-Sinica

Acta Agriculturae Shanghai

Agricultural Chemicals

Anhui Agricultural Science

Beijing Agricultural Science

Guangdong Agricultural Science

Guangxi Agricultural Science
Journals published by provincial or municipal science or agricultural academies

$\begin{array}{llll}+ & + & - & \mathrm{R} \text {; stripe rust of wheat; soybean dodder } \\ + & + & + & \mathrm{R} \text {; fruit and vegetable diseases; wheat scab }\end{array}$

" $\mathrm{TC}=$ table of contents, $\mathrm{AB}=$ abstracts, and $\mathrm{TF}=$ table and figure headings provided in English $+=$ in all issues or for all articles, $\mathrm{o}=\mathrm{occasionally}, \mathrm{or}-$ $=$ never.

${ }^{b}$ Summary of 1986 and 1987 issues, with special research topics characteristic of the journal. $R=$ focus on regional problems; $V=$ variety of subjects, with no particular focus.

${ }^{\mathrm{C}}$ Pergamon Press publishes and distributes an English translation. 
time of use. Use is primarily limited by the working hours of the staff member in charge.

Research unit leadership. The influence of research unit leadership is real but very difficult to measure. Although there are new national directives for the process of research decision making, the history of the interactions between scientific and administrative staff during the tumultuous political and economic changes of the past sets the tone for the present situation. Consequently, each research institute and each laboratory within those institutes may give different weight to the inputs of the individual researchers and the local leadership. What is clear is that the habit of junior researchers unquestioningly yielding to their seniors and the politicized environment in which researchers yield to the policy decisions of the party leaders of their work unit are eroding. This is slowly being replaced by a system in which opinions are valued for their logical appeal. The philosophy of scientific methodology and the norms for professional conduct are currently also being reevaluated in China. Suttmeier (10) presents an accurate and insightful account of this process.

\section{The Chinese Research Journals}

Chinese plant pathologists publish research results principally in domestic journals (Table 2, Fig. 9). These journals are sponsored by national institutes or societies, by municipal or provincial institutes, or by agricultural colleges and universities. However, as the time between submission of a manuscript and final publication is usually more than 1 year, and at times as long as 2 years, some active research groups have resorted to doing their own publishing. Small presses are contracted to do the printing, and the final product is usually stenciled onto newsprint and unbound. The delay is circumvented, but articles thus published are not subject to peer review and have limited circulation. The Bio-
Control Research Group at BAU, for example, publishes 400 copies of quarterly bulletins as the main means of disseminating the results of its studies on the biological control of soilborne diseases. These bulletins are circulated to other researchers in the field and are distributed at regional and national meetings.

Very few Chinese plant pathologists, unless working in collaboration with foreign colleagues, publish independently in the English-language literature. The primary factors dissuading them are the foreign currency needed to cover publication costs and their limited skills in writing scientific articles in English. Those few articles that are published independently abroad are often part of the proceedings of international symposia or have been submitted to journals such as Plant Pathology that ask no publication fee.

Acta Phytopathologica Sinica. This national journal exclusively for plant

Table 2. (continued from preceding page)

\begin{tabular}{|c|c|c|c|c|}
\hline \multirow[b]{2}{*}{ Journal title } & \multicolumn{3}{|c|}{ In Englisha } & \multirow[b]{2}{*}{ Contents related to plant pathology ${ }^{b}$} \\
\hline & TC & AB & TF & \\
\hline Guizhou Agricultural Science & + & o & - & $\mathrm{R} ;$ rice diseases \\
\hline Heilongjiang Agricultural Science & + & - & - & $\mathrm{R}$; soybean diseases and rhizobia; rice diseases \\
\hline Henan Agricultural Science & - & - & - & \\
\hline Hubei Agricultural Science & - & - & - & \\
\hline Hunan Agricultural Science & - & - & - & \\
\hline Jiangsu Agricultural Science & - & - & - & \\
\hline Jilin Agricultural Science & + & + & - & $\mathrm{R}$; soybean and rice diseases \\
\hline Journal of Microbiology & + & + & - & Rhizobium biology; fungal protoplast generation \\
\hline Liaoning Agricultural Science & + & - & - & $\mathrm{R}$; soybean, rice, potato, and sesame diseases \\
\hline Shaanxi Agricultural Science & + & - & - & $\mathrm{R}$; stripe rust of wheat; cotton wilt; rice diseases \\
\hline Shandong Agricultural Science & - & - & - & \\
\hline Shanxi Agricultural Science & - & - & - & \\
\hline Soybean Science & + & + & + & $\begin{array}{l}\mathrm{R} \text {; downy mildew, viruses, and root rot; Rhizobium biology; } \\
\text { disease resistance }\end{array}$ \\
\hline Tianjin Agricultural Science & - & - & - & \\
\hline Xinjiang Agricultural Science & - & - & - & \\
\hline Zhejiang Agricultural Science & - & - & - & \\
\hline \multicolumn{5}{|c|}{ Journals published by agricultural colleges and universities } \\
\hline Acta Agriculturae Universitatis Jilinensis & + & + & - & R; northern corn leaf blight; ginseng diseases \\
\hline Acta Agriculturae Universitatis Pekinensis & + & + & - & $\begin{array}{l}\text { Heterokaryosis of Fusarium wilt of cotton; spatial distribution of } \\
\text { Puccinia striiformis uredospores }\end{array}$ \\
\hline Acta Agriculturae Universitatis Zhejiangensis & + & + & + & $\begin{array}{l}\mathrm{V} \text {; seed bacterization; control of diseases and nematodes of vegetables, } \\
\text { cotton, and ornamentals }\end{array}$ \\
\hline $\begin{array}{l}\text { Acta Universitatis Septentrionali } \\
\text { Occidentali Agriculturae }\end{array}$ & + & + & - & $\begin{array}{l}\mathrm{V} \text {; wheat rust physiology; grape downy mildew genetics and } \\
\text { pathogenicity; spatial distribution of rice blast }\end{array}$ \\
\hline Journal of Anhui Agricultural College & + & + & - & $\begin{array}{l}\mathrm{R} \text {; incidence of apple anthracnose; IPM of cabbage downy mildew } \\
\text { and soft rot; modeling yield loss from rice sheath blight }\end{array}$ \\
\hline Journal of August Ist Agricultural College & + & - & - & $\mathrm{R}$; diseases of crops in arid regions; parasitic plants \\
\hline Journal of Beijing Forestry University & + & o & - & Spread of Dothiorella gregaria within poplar transplants \\
\hline Journal of Fujian Agricultural College & + & + & + & $\begin{array}{l}\mathrm{R} \text {; diseases and nematodes of tropical crops } \\
\text { (rice, sugarcane, and citrus) }\end{array}$ \\
\hline Journal of Hebei Agricultural University & + & + & - & $\mathrm{R}$; leaf rust of wheat; vegetable diseases \\
\hline Journal of Huazhong Agricultural University & + & + & - & $\mathrm{R}$; cotton diseases; cotton-associated mycorrhizae \\
\hline Journal of Hunan Agricultural College & + & + & - & $\mathrm{R}$; rice diseases \\
\hline Journal of Jiangsu Agricultural College & + & + & - & $\mathrm{R}$; esterase isoenzymes of Fusarium graminearum from barley \\
\hline Journal of Nanjing Agricultural University & + & + & - & $\begin{array}{l}\text { V; biology and genetics of phytopathogenic bacteria; parasitic plants; } \\
\text { fungi; viruses }\end{array}$ \\
\hline Journal of Northeast Agricultural College & + & + & - & $\mathrm{R}$; tomato and potato viruses \\
\hline Journal of Shandong Agricultural University & + & + & - & $\mathrm{R}$; tobacco diseases; ectomycorrhizae of tomatoes \\
\hline Journal of Shanghai Agricultural College & + & + & + & R; diseases of ornamentals \\
\hline Journal of Shanxi Agricultural University & + & + & + & $\mathrm{R}$; soybean and cotton diseases \\
\hline Journal of Sichuan Agricultural University & + & + & - & R; Plasmopara taxonomy; plum scab control \\
\hline Journal of South China Agricultural University & + & + & - & $\mathrm{R}$; citrus yellows; papaya mosaic virus; peanut rust \\
\hline Journal of Southwest Agricultural University & + & + & - & $\mathrm{R}$; wheat powdery mildew; rice and citrus nematodes \\
\hline
\end{tabular}


pathology-related articles is published quarterly by CSPP. Currently, two parttime editors are responsible for this and other CSPP publications, but the hiring of a full-time editor is anticipated in 1988.

All submitted manuscripts (handwritten) are first reviewed by the chief editor of CSPP, who passes those meriting further review on to two reviewers. Both reviewers are considered to be actively working in an area closely related to the topic of the manuscript, and one is selected from among the journal's 25 -member editorial board. The remainder of the review process is similar to that for Phytopathology. Every year, 200-300 manuscripts are submitted to Acta Phytopathologica Sinica, and about one-third are rejected.

About 10-15 manuscripts in final form (handwritten) are sent to a contracted press in Beijing about 2.5 months before publication of each issue. The contract stipulates that the press print three drafts for proofreading, each at about 3-week intervals. The Chinese language portion of the entire draft is proofread by one CSPP staff member, and the English abstracts are all edited and proofread by the chief editor. The maximum circulation of Acta Phytopathologica Sinica is about 5,500 copies per issue, of which about 40 are circulated abroad.

Other journals. The other principal journals for research articles related to plant pathology-Acta Phytophylacica Sinica, Chinese Journal of Biological

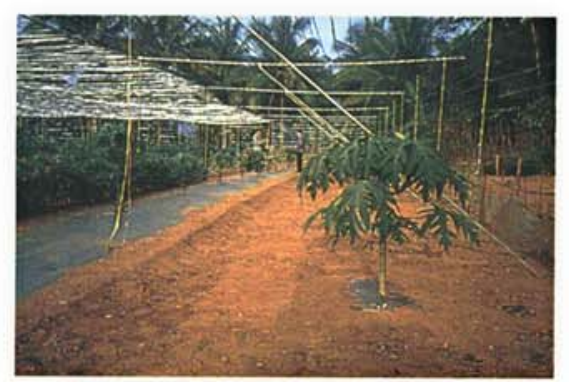

Fig. 8. Reflective tape is used to repel the insect vectors of papaya virus in experimental papaya production at the South China College of Tropical Crops, Hainan Island.

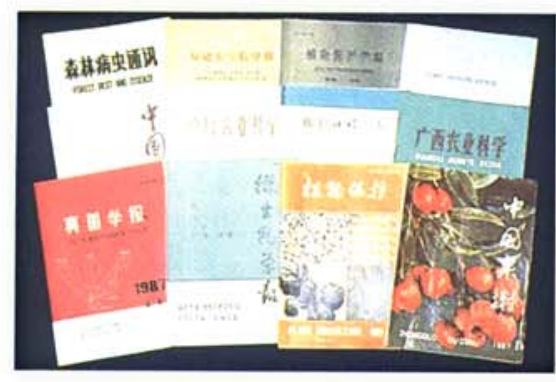

Fig. 9. Some of China's many journals that publish articles related to plant pathology research.
Control, Forest Pest and Disease, and Plant Protection - contain a mixture of disease- and insect-related articles. The audience of Plant Protection is primarily staff of plant protection stations and agricultural bureaus. The remaining journals listed in Table 2 are devoted to broader coverage of the agricultural or natural sciences and contain one to three plant pathology-related articles per issue.

The large number of Chinese journals publishing research articles related to plant pathology suggests a very dynamic system of communicating research findings. However, this system is presently plagued by three problems that greatly limit its effectiveness. The first is the delay in publishing, mentioned previously. This delay is due in part to the laboriousness of manual typesetting of Chinese text, not enough printing houses to meet demand (although Beijing alone has well over 100), and insufficient editorial staff. The editorial staff of most municipal and provincial journals listed in Table 2 falls short of the Ministry of Culture's recommendation that quarterly journals have at least three full-time staff members.

A second limitation is the failure of the agricultural universities and colleges and the provincial research institutes to organize their publication efforts by subject. Currently, at each of these units a small in-house editorial staff is responsible for editing articles on, for example, economics, agricultural mechanization, and veterinary medicine as well as on plant pathology. It has recently been suggested that the State Education Commission direct a reform of the journals of the agricultural schools, consolidating them into five or six speciality journals for each of the northern, northwestern, northeastern, eastern, south central, and southwestern regions of China (13).

But perhaps the most serious limitation of the Chinese scientific literature as a means of disseminating knowledge is the lack of a domestic index system. (Journals published by the national research institutions are cited in some of the international indexes.) Articles in back issues are generally accessed by requesting bibliographies from colleagues working in the field of interest. As the only alternative in searching for relevant literature is to scan the table of contents of each issue of a journal, it is apparent that much of the literature never contributes to the collective body of knowledge. The need for an index system has been recognized and an effort to develop a system compatible with the rules for Chinese library classification has begun (11).

Accessibility to foreign readership. Currently, the bulk of the Chinese plant pathology literature is inaccessible to foreign readership, as the text of the materials and methods and the results sections and most table and figure headings appear only in Chinese. English summaries appear in many journals (Table 2), however, and are informative for determining the types of projects being conducted and for identifying potential collaborators.

The Chinese scientific community recognizes that exclusive use of the Chinese language in publishing isolates them from their colleagues abroad. An effort has begun among plant pathologists to publish more frequently and in greater detail in English. For example, the Department of Plant Protection of BAU is attempting to issue annually a compilation of short research reports in English from department members. The volume would be circulated abroad and presented to visiting scholars. The editorial staff of Acta Phytopathologica Sinica has expressed interest in publishing one issue yearly of English translations of papers selected from the four other issues that year. For both of these endeavors the Chinese seek guidance and cooperation of native English-speaking pathologists for perfecting their English and for proper use of scientific terminology.

The Chinese research journals are distributed abroad by the China International Book Trading Corporation (P.O. Box 2820, Beijing, PRC).

\section{Training at University Level}

Plant pathologists are trained by the plant protection departments of specialized agricultural universities and colleges. There are seven national agricultural universities distributed across China and one (occasionally two) locally administered agricultural college or university in each of the 29 provinces (including the autonomous regions and municipalities). Teaching in forest pathology is usually provided by the plant protection departments of the three forestry universities and three colleges. Most of these institutions now offer both undergraduate and graduate programs.

Undergraduate programs. Access to undergraduate programs in plant pathology is gained by successful performance in a written, highly competitive national examination usually taken just after graduating from high school. The examination is common for all scientific programs in all colleges and universities of China and includes seven subjects (Chinese, English, mathematics, physics, chemistry, biology, and politics). The assignment of each student to a particular university department is based on the compatibility of the student's score with the minimal eligibility score required for the desired study program. The procedure is further complicated by a score compensation system based on the province of origin of the student and aimed at fostering a higher level of education among the residents of certain self-labeled "less developed" provinces. 
While registering for the examination, each student must present a list of three specific programs (a given department in a given university or college) in order of preference. This choice is usually the object of dread and careful thinking by the student (and often his or her family) because it requires a delicate balance between the student's projected ambitions and potential performance in relation to those of other competitors. Occasionally, a student with honorable scores fails the examination because the scores required for the three programs chosen are all higher than that obtained in the examination. On the basis of performance in the examination, students may be assigned to institutions of much lower academic level than they could have accessed because they were unaware of their abilities relative to those of their peers. Students often readily admit that they had no particular prior interest in the field of study and university they are attending, but "it seemed like a safe choice."

Undergraduate students are attached to a department from the beginning of their freshman year and can change only under rare circumstances. Plant protection departments in agricultural universities throughout China typically enroll 60 freshmen every year, usually organized in two classes of 30 students. In contrast with other universities, the Department of Plant Protection at BAU has been divided into two administrative divisions, plant pathology and entomology, since the late 1950s. It now enrolls 30 students in each division. Other universities (e.g., South China Agricultural University, Nanjing Agricultural University) have begun to offer a distinct curriculum for entomology and plant pathology. The Department of Plant Protection at Nanjing Agricultural University enrolls undergraduates in entomology, plant pathology, and plant protection divisions, with 15,15 , and 30 students per division, respectively. Students in the plant protection division are destined to work in administrative or extension positions at the provincial or county level, whereas those in the entomology and plant pathology divisions will staff research or teaching institutions.

The 4-year curriculum for a B.S. degree in plant protection with speciality in plant pathology is established in each university by the teaching affairs committee of the department or division, based on the guidelines and rules set up by the State Education Commission. The curriculum is very similar throughout China and comparable to that in Western universities. Students usually take 40 required foundation courses totaling 2,000 hours (including 550 hours of laboratory training and 90 hours of field courses) in basic and applied sciences. The six plant pathology courses required at BAU are taken in the junior and senior years and include nearly as much laboratory training as lecture time. Additional required courses are four semesters of English (or other foreign language), four semesters of physical education, and a class on the history of the Chinese revolution, one on political economics, and one on Marxist philosophy. Required course work is complemented by 200 hours worth of elective courses, most of which are taken in plant pathology. One consequence of the isolation of students on campuses of specialized agricultural universities is that the choice of elective courses is mostly limited to disciplines related to biology and agriculture.

Although less emphasized than in the past, practical training is still important in the curriculum. Beginning in the fall semester of 1987, freshmen in Chinese universities are provided with several weeks of military training. At the beginning of their second year, students from all departments are sent for 4 weeks to the countryside, usually to an experimental farm, where they participate in the various types of physical labor practiced on a farm.

The last semester of undergraduate studies is spent in a laboratory where the student works on a research project under the supervision of a faculty member. In order to graduate, the students must write a bachelor's thesis and present their results in a public seminar.

Graduate programs. After a long interruption due to the Cultural Revolution, agricultural universities began enrolling students again in master's programs in 1978 and in doctorate programs in 1983. Only a few senior professors have the authority to supervise doctoral research work in plant pathology. For example, at present there are five such professors at BAU, one at Nanjing Agricultural University, and one at the South China Agricultural University.

Master's program. Access to a master's program in plant pathology is gained through a nationwide graduate entrance examination typically taken during the winter of the senior undergraduate year. Students are tested in five written subjects (English, chemistry or mathematics, biochemistry and plant physiology, plant pathology, and politics). The students who pass the written test then face an oral examination or interview with the professor with whom they wish to work. Before registering for the graduate entrance examination a student must choose and apply for one graduate advisor from the list of associate professors and professors who are authorized by the State Education Commission to enroll a master's student that year. Famous professors may have more than 10 applicants nationwide compete for one position in their

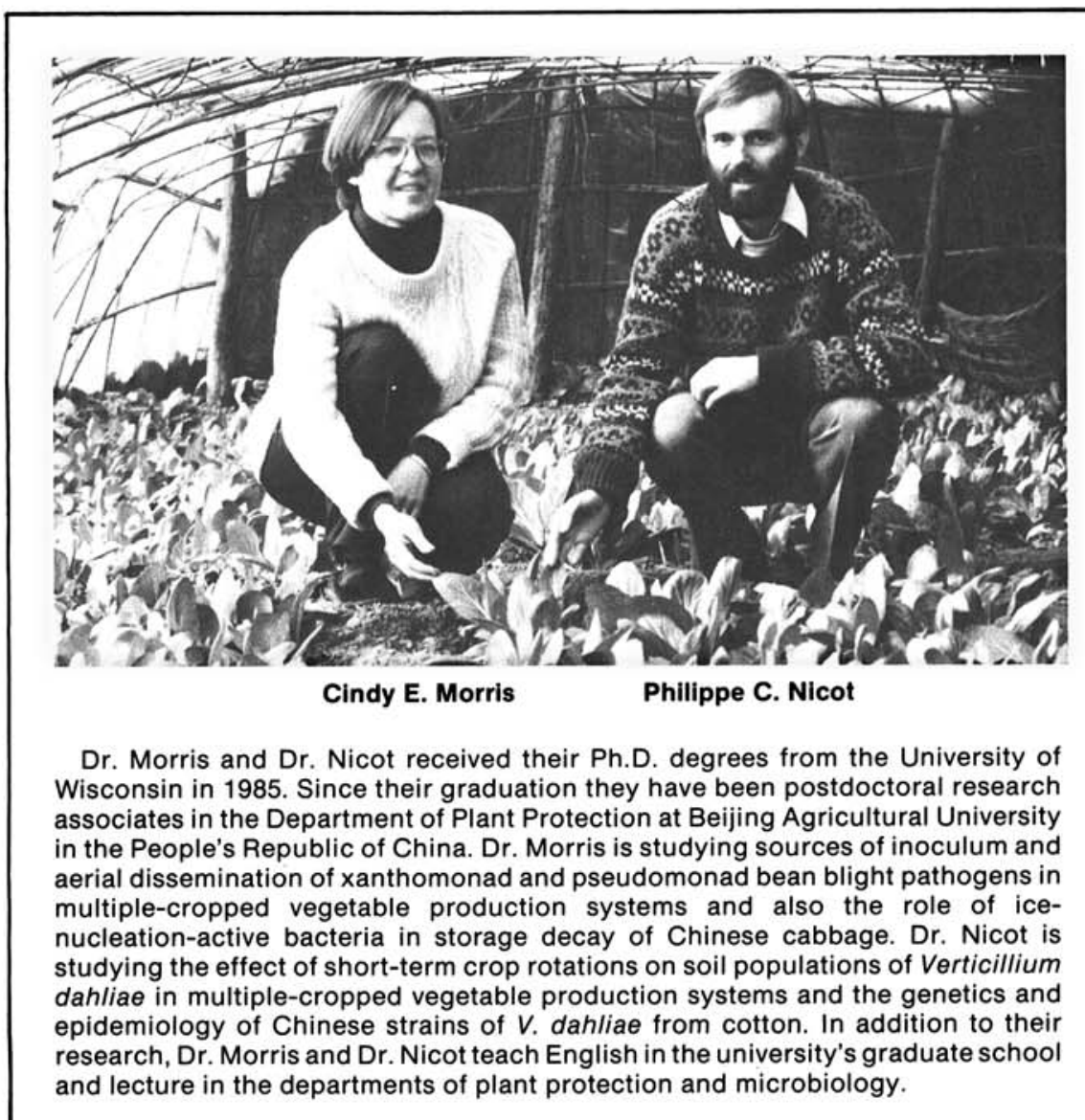


laboratory. Students who fail in the examination may be given a second chance but must wait 2 years before applying again.

The successful applicants enter a 3year curriculum in which course work is usually emphasized during the first year and the last three semesters are entirely dedicated to research. Six courses, for a total of 16-18 credits, are required for all students: two semesters of English; "Advances in Plant Pathology" seminars; one of four "Etiology" courses (fungal-, bacterial-, viral-, or nematode-induced diseases), depending on the student's research speciality; "Specialized Plant Pathology," with a choice among four subjects (physiological plant pathology, ecological plant pathology, epidemiology, and plant immunology), depending on the student's specialization; and one course in Marxist theory (usually "Natural Dialectics"). A working knowledge of a foreign language (usually English) is a strict requirement, and students who do not pass the language course are usually dismissed from the graduate school. An additional 30-35 credits must be obtained from elective courses in plant pathology or related sciences. While required courses tend to be similar throughout China, a greater variety exists in the types of elective classes offered, depending on the expertise at the different universities. The Plant Pathology Division at BAU offers about 30 elective courses, mostly in plant pathology. No minor field of study is required. Master's programs are currently also offered in institutes of the CAS and CAAS. Although graduate students in these institutions have access to excellent facilities and expertise in their field of research, it is often difficult for these institutions to provide the courses required for a master's program. This problem is usually solved through cooperation with the agricultural universities. A master of science degree in plant pathology is granted after the student writes a thesis and defends the research results before an examination committee of about six professors in a public seminar.

Doctorate program. To enter a doctorate program, students take an examination organized by the institution they wish to attend. In contrast with the graduate entrance examination, each institution is granted wide autonomy to design the schedule and contents of the doctorate examination, and students may apply to several institutions if the schedules allow them to take several examinations. Test subjects include English and two scientific disciplines related to the student's proposed field of research. The students who pass the written tests are given an oral examination by the professor with whom they wish to study. The State Education Commission names the professors authorized to grant doctorate degrees and determines the number of students they may take each year.

The doctorate curriculum generally lasts 3 years, during which students mostly conduct research. The only required courses are two semesters of English, two of a second foreign language, and one of Marxist theory. As in the master's program, students who fail the English class are not permitted to pursue their graduate studies. Other courses may be taken as needed by the student's specific research project. In contrast with master's programs, doctorate students may be granted initiative in the design and execution of their research project. The first doctorate degrees in plant protection since 1949 are to be granted in 1988.

Job placement. After graduating, students are assigned to a work unit by the administration of their university. Assignment is based on some combination of the requests for university graduates from work units across the country, the preference of the students, and their province of origin. Students are often sent back to work in their home province. Some students have been successful in facilitating their own placement.

\section{Conclusion}

The status of plant pathology in China today contrasts dramatically with the reports of the Western plant pathologists who first visited the People's Republic in the mid- and late 1970s. The people's communes have been disbanded, and establishment of the household contract responsibility system and free markets for certain produce has resulted in increased crop output. These changes have affected agriculture at all levels of production and, coupled with the diminishing rural labor force, have serious implications for plant disease control. National funds for research are being distributed in a manner that promotes efficiency and quality of research, closer links between researchers and industry are encouraged, and opportunities for access to advanced technologies have increased. All of this is reflected in the changes that have occurred in plant pathology over the last decade.

But the next decade may witness equally significant changes for plant pathology. Because of their age, many of the prominent leaders of CSPP - who have guided the society since its founding - will retire. These leaders have had opportunities for advanced education and to work and study abroad, are fluent in several languages, and play active roles in national or local funding and policymaking organizations such as the National People's Congress and CAST. Promoting new leaders with equal competence and influence is the next challenge Chinese plant pathologists must face in their effort to get the job done.

\section{Acknowledgments}

We thank Di Yuan-bo, Xu Xiao-hua, Shen Qi-yi, Li Qing-ji, and Tang Wen-hua for their many efforts to facilitate our research and teaching in the Department of Plant Protection, BAU; the staff and students of that same department for assistance with translations of information we needed for this paper; and the administration of BAU, the Ministry of Agriculture, Animal Husbandry and Fisheries of the PRC, and the U.S. National Academy of Sciences CSCPRC. For the time they took to review the manuscript and for their useful comments we thank Chiu Wei-fan, Shen Qi-yi, Tang Wen-hua, Zeng Shi-mai, and Yang Li-li of BAU, P. H. Williams and A. Kelman of the University of Wisconsin-Madison, and Kyna Rubin of the CSCPRC.

\section{Literature Cited}

1. Anderson, A., and Maddox, J. 1985. Science in China: Industrial power by research? Nature 318:205-228.

2. Anonymous. 1983. Science in China: Planting a tall tree. Nature 301:280-284.

3. Chiu, W. F., and Chang, Y. H. 1982. Advances of science of plant protection in the People's Republic of China. Annu. Rev. Phytopathol. 20:71-92.

4. Ford, R. E., Bissonnette, H. L., Horsfall, J. G., Millar, R. L., Schlegel, D., Tweedy, B. G., and Weathers, L. G. 1981. Plant pathology in China, 1980. Plant Dis. 65:706-714.

5. Kelman, A., and Cook, R. J. 1977. Plant pathology in the People's Republic of China. Annu. Rev. Phytopathol. 15:409-429.

6. Lardy, N. R. 1984. Prices, markets, and the Chinese peasant. Pages $420-435$ in: Agricultural Development in the Third World. C. K. Eicher and J. M. Staatz, eds. The Johns Hopkins University Press, Baltimore.

7. Metcalf, R. L., and Kelman, A. 1980. Plant protection. Pages 313-344 in: Science in Contemporary China. L. A. Orleans, ed. Stanford University Press, Stanford, CA.

8. Needham, J. 1978. Science reborn in China. Nature 274:832-839.

9. Sprague, G. F. 1975. Agriculture in China. Science 188:549-555.

10. Suttmeier, R. P. 1984. New conflicts in the research environment. Bull. At. Sci. 40(Suppl.):2s-15s.

11. Wang, Y. X. 1987. The establishment and utilization of the index system for scientific and technological information exchange. J. Hebei Agric. Univ. 10(2):144149. (In Chinese)

12. Williams, P. H. 1979. Vegetable crop protection in the People's Republic of China. Annu. Rev. Phytopathol. 17:311-324.

13. Wu, C. L. 1987. Exploring reformation of the journals of agricultural universities. J. Gansu Agric. Univ. 1987(1):125-133. (In Chinese)

14. Xue, M. Q. 1987. Socialism and planned commodity economy. Beijing Rev. 30(33):14-19.

15. Zhang, B. C. 1988. Plant pathology in China: History and status. Rev. Plant Pathol. In press. 